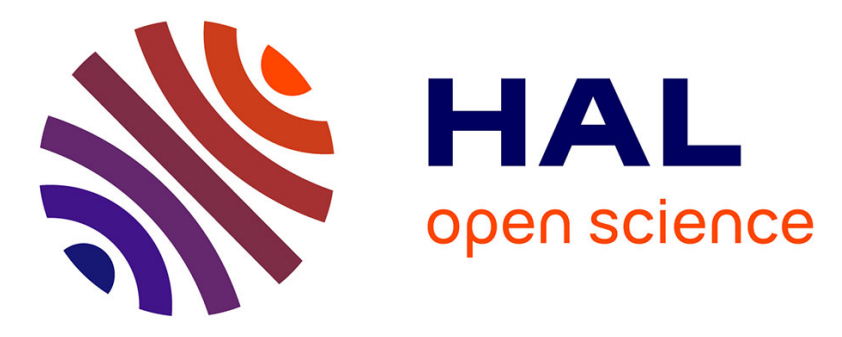

\title{
Demographics, health and travel characteristics of international travellers at a pre-travel clinic in Marseille, France
}

\author{
Camille Aubry, Jean Gaudart, Catherine Gaillard, Jean Delmont, Philippe \\ Parola, Philippe Brouqui, Philippe Gautret
}

\section{To cite this version:}

Camille Aubry, Jean Gaudart, Catherine Gaillard, Jean Delmont, Philippe Parola, et al.. Demographics, health and travel characteristics of international travellers at a pre-travel clinic in Marseille, France. Travel Medicine and Infectious Disease, 2012, 10.1016/j.tmaid.2012.09.004 . hal-01307761

\section{HAL Id: hal-01307761 \\ https://hal-amu.archives-ouvertes.fr/hal-01307761}

Submitted on 26 Apr 2016

HAL is a multi-disciplinary open access archive for the deposit and dissemination of scientific research documents, whether they are published or not. The documents may come from teaching and research institutions in France or abroad, or from public or private research centers.
L'archive ouverte pluridisciplinaire HAL, est destinée au dépôt et à la diffusion de documents scientifiques de niveau recherche, publiés ou non, émanant des établissements d'enseignement et de recherche français ou étrangers, des laboratoires publics ou privés.

\section{(1) (1) $\$$}

Distributed under a Creative Commons Attribution - NonCommercial - NoDerivatives| 4.0 


\title{
Demographics, health and travel characteristics of international travellers at a pre-travel clinic in Marseille, France
}

\section{Camille Aubry $^{a}$, Jean Gaudart ${ }^{b}$, Catherine Gaillard ${ }^{a}$, Jean Delmont ${ }^{a}$, Philippe Parola ${ }^{a}$, Philippe Brouqui ${ }^{a}$, Philippe Gautret ${ }^{\text {a,* }}$}

\author{
${ }^{a}$ University Hospital Institute for Infectious and Tropical Diseases, Hôpital Nord, AP-HM, 13015 Marseille, France \\ ${ }^{\mathrm{b}}$ LERTIM, Faculty of Medicine, Aix-Marseille University, Marseille, France
}

Received 30 July 2012; received in revised form 10 September 2012; accepted 12 September 2012

Available online 11 October 2012

\section{KEYWORDS \\ Travellers; \\ Demographics; \\ Chronic conditions; \\ Vaccination; \\ Antimalarials}

\begin{abstract}
Summary With the aim to identify at-risk individuals among a cohort of international travellers, 3442 individuals who sought advice at Marseille travel health centre in 2009 were prospectively included. Demographics, travel characteristics, chronic medical conditions, vaccinations and antimalarial chemoprophylaxis were documented.

Chronic medical conditions were reported by $11 \%$ of individuals, including hypertension $(39 \%)$, asthma $(20 \%)$, thyroid disease $(15 \%)$ and depression $(13 \%) .4 \%$ reported taking a daily medication, and psychotropic and cardiovascular medications were the most commonly used. Older travellers ( $\geq 60$ years) accounted for $10 \%$ of the travellers and the prevalence of chronic medical conditions was $27 \%$ in this group. Individuals aged 15 years or less accounted for $13 \%$ of the travellers. Age, last minute travel $(17 \%)$ and neurological and psychiatric diseases were the most frequent factors that influenced Yellow fever vaccination and malaria chemoprophylaxis, with more than one tenth of the travellers reporting at least one risk factor for which adjusted advice may be necessary. Migrants visiting their relatives in their origin country accounted for $14 \%$ of travellers and $73 \%$ of this group travelled with their family including young children.

We demonstrate that a significant proportion of travellers are at-risk $(43 \%)$ because of their travel conditions (VFR), their age, or their health status, and should be targeted for risk reduction strategies.
\end{abstract}

(c) 2012 Elsevier Ltd. All rights reserved.

\footnotetext{
* Corresponding author. Tel.: +33 (0) 4919635 35; fax: +33 (0) 491968938.

E-mail address: philippe.gautret@club-internet.fr (P. Gautret).
} 


\section{Introduction}

Over 80 million people travel annually from industrialised countries to the developing world, and this trend continues to increase. ${ }^{1}$ European travellers account for the majority of international travellers, and travel-associated diseases are frequent among this mobile population. ${ }^{2}$ In 2006, 22.5 million French citizens travelled abroad to the following countries: Europe (33\%), North Africa (12\%), Asia (7\%), the Caribbean (4\%), Latin America (2\%), the Indian Ocean (2\%), Sub-Saharan Africa (2\%), the Middle East (1\%) and Oceania $(1 \%){ }^{3} \mathrm{~A}$ total of 120 countries were visited, of which one out of four were considered to be at high-risk for travelassociated diseases. ${ }^{3}$ This risk is notable for infectious diseases that are associated with food and water consumption, arthropod bites, environmental conditions and sexual behaviour and is frequently underestimated by travellers. In a study that was conducted in airports in Europe of travellers to tropical countries, only $50 \%$ of travellers had sought pre-travel advice and only one-third of travellers to malaria-endemic countries took antimalarial chemoprophylaxis. ${ }^{4}$ In France, a telephone survey that was conducted among individuals $18-79$ years of age revealed that $75 \%$ of respondents considered it useful to seek medical advice prior to travelling, but only $63 \%$ of the respondents sought advice. ${ }^{5}$ Because of the increasing number of international travellers to at-risk destinations, pre-travel advice is a key point in a public health perspective, which limits the burden of travel-associated diseases in French travellers and the risk of importation of communicable diseases in France. Over 100 specialised pre-travel clinics were recorded in a national survey that was conducted in 2009 in France, of which five clinics were in the Bouches du Rhône district in Southern France $(1,995,094$ inhabitants in 2009), including three clinics in the largest city, Marseille $\left(858,902\right.$ inhabitants in 2009). ${ }^{6}$

Published data regarding the characteristics of French travellers are scant and limited to specific categories of travellers or specific travel destinations. ${ }^{7-9}$ With the aim to identify at-risk travellers departing from Marseille, we conducted a study on individuals who sought advice at a travel health centre in 2009.

\section{Materials and methods}

\section{Study travellers}

All of the travellers who presented to the travel health centre at a tertiary care hospital (University Institute for Infectious and Tropical Diseases, Marseille) were included prospectively in a study from January 2009 to December 2009. Travellers to Mecca who were participating in the Hajj were excluded because a specific survey was conducted in this population. ${ }^{10}$ In addition, travellers who were consulted for a systematic vaccination for business travel with no specific travel destination (air and navy crew) were excluded. A total of 8 medical doctors documented the demographics (gender, age, and socioprofessional category according to the INSEE classification ${ }^{11}$ ), travel characteristics (visit date, departure date, countries travelled to, travel duration, reason for travel, number of co-travellers, and risk level) and medical conditions (chronic diseases, treatments, and pregnancy). Additionally, prescribed vaccinations and antimalarial chemoprophylaxis were documented. The factors that influenced standard pre-travel health advice were documented according to the Van de Winkel criteria addressing condition with possible interaction with malaria prevention and Yellow fever vaccination, and preventive measures for travellers' diarrhoea and other enteric infections. Details about what constitutes a possible interaction or a possible influencing factor are described elsewhere. ${ }^{12}$

\section{Statistical analysis}

The data were entered anonymously and managed in the SPSS software package, v16.0 (SPSS Inc., Chicago). The differences in the proportions (categorical variables) were tested by Fisher's exact tests, and the differences in the medians (continuous variables) were tested by the Kruskal-Wallis test. $p$ Values $<0.05$ were considered statistically significant.

\section{Results}

\section{Traveller and travel characteristics}

A total of 3957 travellers presented to the centre over the study period, of whom $479(11.8 \%)$ were Hajj pilgrims and $36(0.9 \%)$ were air and navy crew. A total of 3442 travellers were included in the study. The mean number of visits per month was 285 (Fig. 1). There was a 1.4 fold increase in the number of visits in June and a 1.2 fold increase in July due to departures for summer scholar vacations. A decrease in the number of visits was observed in April, May and August for internal reasons and in October because most of the consultants were Hajj pilgrims during this month. The $M / F$ sex ratio was 0.98 , and the mean age was 36.6 years (range $=1$ month -85 years). Individuals who were $\leq 18$ years of age accounted for $14.9 \%$ of the travellers, including 459 children $\leq 15$ years of age and 48 children $\leq$ one year of age. Older travellers who were $\geq 60$ years of age accounted for $10.4 \%$ of the travellers (Table 1). Among the travellers $>18$ years of age, $62.0 \%$ of the socio-professional

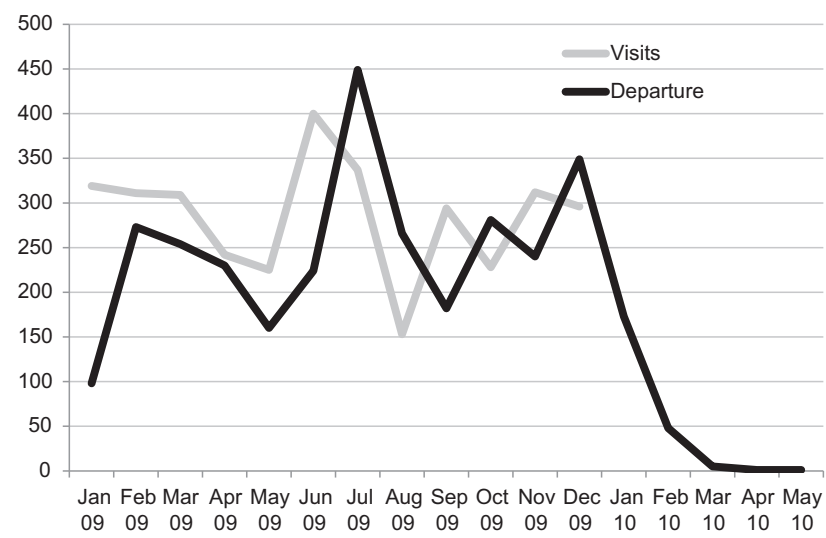

Figure 1 Number of visits and travel departure per month of 3442 travellers from Marseille, in 2009-2010. 
Table 1 Demographics and travel characteristics of 3442 travellers from Marseille, according to reason for travel in 2009.

\begin{tabular}{|c|c|c|c|c|c|}
\hline & & All travellers $N(\%)$ & Tourists N (\%) & $\begin{array}{l}\text { Business } \\
\text { travellers N (\%) }\end{array}$ & VFRs $^{\mathrm{a}} N(\%)$ \\
\hline \multirow[t]{2}{*}{ Gender } & Male & 1709 (49.6) & 925 (46.9) & $392(69.3)$ & $211(47.8)$ \\
\hline & $N D^{b}$ & 3 & 1 & 0 & 1 \\
\hline \multirow[t]{4}{*}{ Age (years) } & $0-17$ & 504 (14.9) & $235(12.1)$ & $39(7.0 \%)$ & $173(39.5)$ \\
\hline & $18-59$ & $2533(74.7)$ & $1445(74.7)$ & $481(86.7 \%)$ & $240(54.8)$ \\
\hline & $>60$ & $352(10.4)$ & $255(13.2)$ & $35(6.3 \%)$ & $25(5.7)$ \\
\hline & ND & 53 & 35 & 11 & 3 \\
\hline \multirow{8}{*}{$\begin{array}{l}\text { Socio-professional } \\
\text { category ( } \leq 18 \text { years } \\
\text { of age) }\end{array}$} & Farmer & $4(0.2)$ & $3(0.3)$ & $1(0.3)$ & $0(0.0)$ \\
\hline & $\begin{array}{l}\text { Contractor/ } \\
\text { Craftsman }\end{array}$ & $95(5.3)$ & $46(4.2)$ & $33(9.6)$ & $7(5.7)$ \\
\hline & Business executive & $425(23.7)$ & $250(22.8)$ & $129(37.4)$ & $10(8.2)$ \\
\hline & $\begin{array}{l}\text { Intermediate } \\
\text { profession }\end{array}$ & $472(26.4)$ & $298(27.2)$ & $101(29.3)$ & $29(23.8)$ \\
\hline & Employee & $241(13.5)$ & $155(14.1)$ & $47(13.6)$ & 23 (18.9) \\
\hline & Factory worker & $29(1.6)$ & $11(1.0)$ & $12(3.5)$ & $7(5.7)$ \\
\hline & Retired & $251(14.0)$ & $206(18.8)$ & $6(1.7)$ & $18(14.8)$ \\
\hline & $\begin{array}{l}\text { Student/ } \\
\text { Unemployed }\end{array}$ & $272(15.2)$ & $128(11.7)$ & $16(4.6)$ & $28(23.0)$ \\
\hline \multirow[t]{7}{*}{ Travelled regions } & Africa & $2252(65.8)$ & 1150 (58.7) & $391(70.1)$ & $394(89.3)$ \\
\hline & America & $638(18.6)$ & $441(22.5)$ & $98(17.6)$ & $30(6.8)$ \\
\hline & Asia & $485(14.2)$ & 337 (17.2) & $59(10.6)$ & 17 (3.9) \\
\hline & Oceania & $14(0.4)$ & $3(0.2)$ & $9(1.6)$ & $0(0.0)$ \\
\hline & Europe & $1(0.0)$ & $0(0.0)$ & $0(0.0)$ & $0(0.0)$ \\
\hline & Round the world & $33(1.0)$ & $29(1.5)$ & $1(0.2)$ & $0(0.0)$ \\
\hline & ND & 39 & 13 & 8 & 0 \\
\hline \multirow[t]{10}{*}{$\begin{array}{l}\text { Travelled countries } \\
\quad \text { (top 10) }\end{array}$} & & Senegal 657 (21.6) & $\begin{array}{l}\text { Senegal } 474 \\
(25.9)\end{array}$ & $\begin{array}{l}\text { French Guyana } 61 \\
\text { (11.6) }\end{array}$ & $\begin{array}{l}\text { Comoros } 112 \\
(25.5)\end{array}$ \\
\hline & & Kenya 187 (6.1) & Kenya 170 (9.3) & Gabon $45(8.6)$ & Senegal 83 (18.9) \\
\hline & & Brazil 161 (5.3) & Brazil 116 (6.3) & Senegal 38 (7.2) & $\begin{array}{l}\text { Côte d'ivoire } \\
38(8.6)\end{array}$ \\
\hline & & $\begin{array}{l}\text { Burkina Faso } \\
154(5.1)\end{array}$ & Tanzania 77 (4.2) & Mali 37 (7.0) & $\begin{array}{l}\text { Madagascar } \\
27(6.1)\end{array}$ \\
\hline & & $\begin{array}{l}\text { French Guyana } \\
151(5.0)\end{array}$ & India 76 (4.2) & $\begin{array}{l}\text { Côte d'ivoire } \\
35(6.7)\end{array}$ & Guinea 16 (3.6) \\
\hline & & Mali $147(4.8)$ & Peru 74 (4.0) & $\begin{array}{l}\text { Cameroun } \\
32(6.1)\end{array}$ & $\begin{array}{l}\text { Burkina Faso } \\
16(3.6)\end{array}$ \\
\hline & & Comoros 127 (4.2) & Thailand 72 (3.9) & Congo 26 (4.9) & $\begin{array}{l}\text { French Guyana } \\
16(3.6)\end{array}$ \\
\hline & & $\begin{array}{l}\text { Côte d'ivoire } \\
121(4.0)\end{array}$ & Mali 67 (3.7) & Angola 25 (4.8) & $\begin{array}{l}\text { Cameroun } \\
14(3.2)\end{array}$ \\
\hline & & India 95 (3.1) & $\begin{array}{l}\text { Burkina Faso } \\
65(3.6)\end{array}$ & $\begin{array}{l}\text { South Korea } \\
24(4.6)\end{array}$ & Benin 13 (3.2) \\
\hline & & Tanzania 86 (2.8) & $\begin{array}{l}\text { French Guyana } \\
65(3.6))\end{array}$ & $\begin{array}{l}\text { Burkina Faso } \\
22(4.2)\end{array}$ & Gabon 13 (3.2) \\
\hline \multirow{4}{*}{$\begin{array}{l}\text { Number of countries } \\
\text { per travel }\end{array}$} & 1 country & 3105 (90.9) & $1780(90.4)$ & 512 (91.9) & 435 (98.9) \\
\hline & $>1$ country & $278(8.1)$ & $152(7.7)$ & $45(8.1)$ & $5(1.1)$ \\
\hline & Round the world & $33(1.0)$ & $29(1.5)$ & $0(0.0)$ & $0(0.0)$ \\
\hline & ND & 39 & 12 & 8 & 0 \\
\hline \multirow{8}{*}{$\begin{array}{l}\text { Mean travel duration } \\
\text { (weeks) }\end{array}$} & $\leq 1$ & $495(15.4)$ & $313(16.4)$ & $138(27.6)$ & $11(2.6)$ \\
\hline & $1-2$ & $1224(38.1)$ & $969(50.7)$ & $82(16.4)$ & $81(19.3)$ \\
\hline & $>2-4$ & $733(22.8)$ & $429(22.3)$ & 57 (11.4) & $150(35.7)$ \\
\hline & $>4-12$ & $426(13.3)$ & $118(6.3)$ & $62(12.2)$ & $166(39.3)$ \\
\hline & $>12-36$ & $126(3.9)$ & 37 (1.9) & $48(9.6)$ & $3(0.7)$ \\
\hline & $>36-52$ & $76(2.3)$ & $24(1.2)$ & $47(9.6)$ & $2(0.7)$ \\
\hline & $>52$ & $135(4.2)$ & $22(1.2)$ & $66(13.2)$ & $7(1.7)$ \\
\hline & ND & 226 & 61 & 66 & 21 \\
\hline
\end{tabular}


Table 1 (continued)

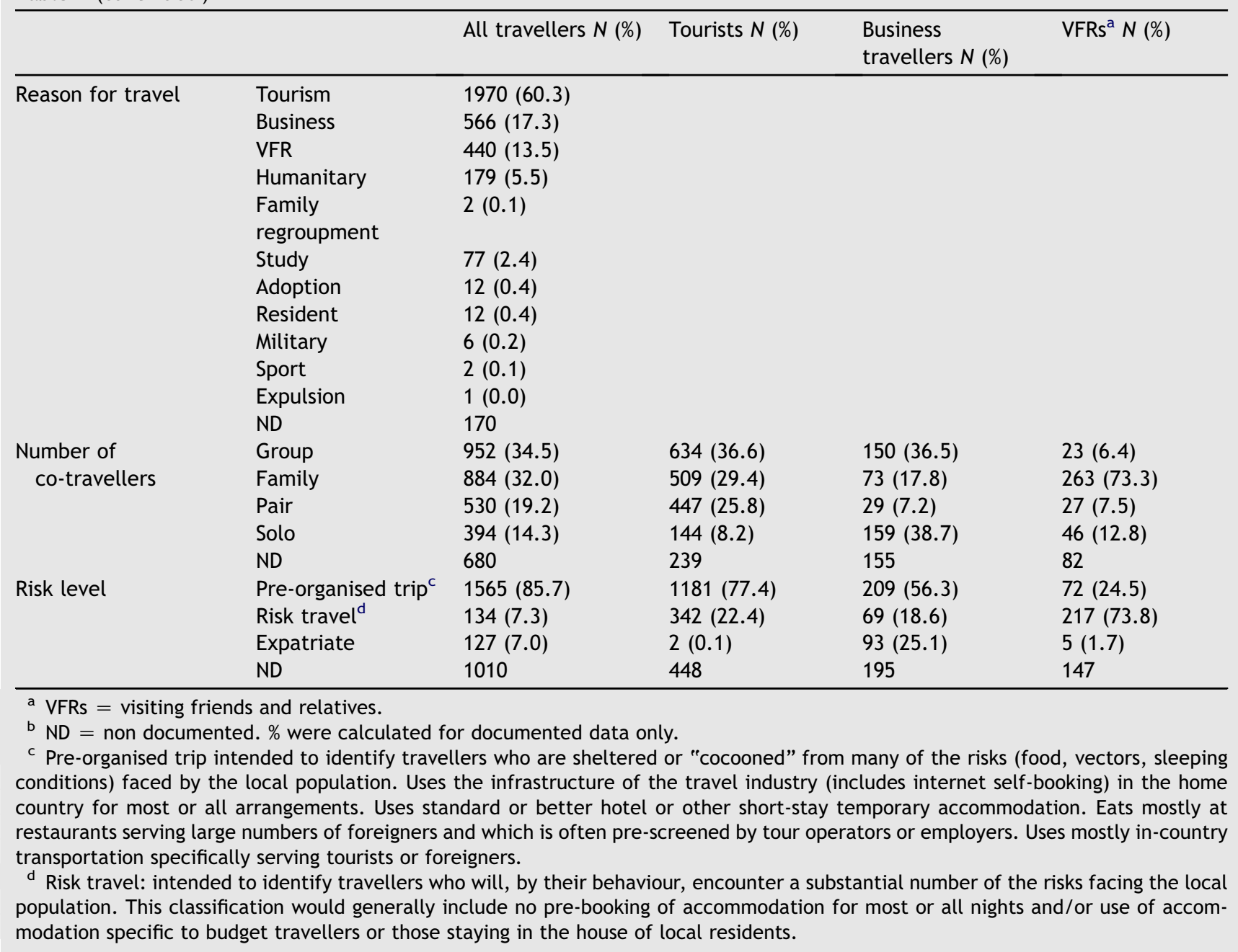

categories were documented. Of these travellers, $70.7 \%$ were working currently, $14.0 \%$ were retired and $15.2 \%$ were students or unemployed. Of 10 travellers, 7 planned to travel to Africa, 2 to the American continent and 1 to Asia. The top 10 visited countries were Senegal, Kenya, Burkina Faso, French Guyana, Mali, Comoros, Côte d'Ivoire, India and Tanzania. Overall, $90.9 \%$ of the travellers planned to visit only one country. The mean travel duration for individuals who were travelling $\leq$ one year $(95.8 \%$ ) was 5.6 weeks (range $=0.1-52$ weeks). The travel duration was $\leq 2$ weeks for $53.5 \%$ of the travellers, $\leq$ one month for $76.3 \%,>3$ months for $10.4 \%$ and $>$ six months for $6.5 \%$. The mean time between the visit date and the departure date was 32.4 days (range $=0-269$ days), and $17.2 \%$ of the travellers were consulted $\leq 10$ days before departing, $44.8 \% \leq 21$ days and $57.4 \% \leq 28$ days. The most common reasons for travel were tourism, business and visiting friends and relatives (VFR). The majority of travellers travelled at least by pair and underwent pre-organised trips.

The demographics and travel characteristics varied according to the reason for travel. Tourists and business travellers were older than VFRs (37.6 and 38.9 years of age vs. 26.3 years of age, $p<0.001)$. Africa was the most common destination among the three groups of travellers. Overall, $69.4 \%$ of the travellers the American continent and
$71.5 \%$ of the travellers to Asia were tourists. The top 3 visited countries were Senegal, Kenya and Brazil among tourists; French Guyana, Gabon and Senegal among business travellers; and Comoros, Senegal and Côte d'Ivoire among VFRs. Tourists had a shorter travel duration (4.0 weeks, range $=0.5-52$ weeks) compared to VFRs ( 5.2 weeks, range $=0.3-40$ weeks) and business travellers (10.4 weeks, range $=0.1-52$ weeks) with $p<0.001$. Tourist travellers were less likely to travel with their families compared to VFRs $(32.0 \%$ vs. $73.3 \%)$, and tourists and business travellers underwent pre-organised trips more frequently compared to VFRs $(77.4 \%$ and $56.3 \%$ vs. $24.5 \%)$ with $p<0.001$.

\section{Medical conditions}

Among female travellers $16-50$ years of age $(N=1091$, $63.0 \%$ of female travellers), eight travellers were pregnant, 18 were trying to conceive and two were breastfeeding. One or more medical conditions were identified in $11.3 \%$ of the travellers (Table 2). The mean age of travellers with chronic medical conditions was 45.1 years, and the $M / F$ sex ratio was 1.3 . The prevalence of chronic medical conditions was $27.0 \%$ in travellers $\geq 60$ years of age, $9.9 \%$ in travellers 
Table 2 Chronic medical conditions in 3442 travellers from Marseille in 2009.

\begin{tabular}{|c|c|c|c|c|}
\hline Syndrome $(N)$ & Disease & $\begin{array}{l}\text { Travellers } \\
(\mathrm{N})\end{array}$ & $\begin{array}{l}\% \text { of ill } \\
\text { travellers }\end{array}$ & $\begin{array}{l}\% \text { of all } \\
\text { travellers }\end{array}$ \\
\hline \multirow[t]{7}{*}{ Cardiovascular (215) } & Hypertension & 150 & 38.6 & 4.6 \\
\hline & Myocardial infarction/Angor & 29 & 7.5 & 0.9 \\
\hline & Heart rhythm and conduction disorder & 13 & 3.3 & 0.4 \\
\hline & Thromboembolic disease & 9 & 2.3 & 0.3 \\
\hline & Cardiopathy & 2 & 0.5 & 0.1 \\
\hline & Valvular disease & 3 & 0.8 & 0.1 \\
\hline & Other & 3 & 0.8 & 0.1 \\
\hline \multirow[t]{4}{*}{ Endocrinology (109) } & Thyroid disease & 57 & 14.7 & 1.7 \\
\hline & Diabetes & 45 & 11.6 & 1.4 \\
\hline & Dyslipidemiae & 15 & 3.9 & 0.5 \\
\hline & Other & 7 & 1.8 & 0.2 \\
\hline \multirow[t]{3}{*}{ Respiratory (87) } & Asthma & 77 & 19.8 & 2.4 \\
\hline & Cystic fibrosis & 2 & 0.5 & 0.1 \\
\hline & Other (Quincke oedema-rhinitis) & 6 & 1.5 & 0.2 \\
\hline \multirow[t]{2}{*}{ Psychiatric (53) } & Depression & 49 & 12.6 & 1.5 \\
\hline & Other (anxiety-psychosis-autism) & 3 & 0.8 & 0.1 \\
\hline Cancer (36) & Cancer & 37 & 9.5 & 1.1 \\
\hline \multirow[t]{4}{*}{ Neurologic (36) } & Migraine & 16 & 4.1 & 0.5 \\
\hline & Epilepsy & 12 & 3.1 & 0.4 \\
\hline & Stroke & 7 & 1.8 & 0.2 \\
\hline & $\begin{array}{l}\text { Other (Guillain Barré-multiple } \\
\text { sclerosis-myasthenia-myelitis) }\end{array}$ & 4 & 1.0 & 0.1 \\
\hline \multirow[t]{3}{*}{ Gastrointestinal diseases (32) } & Crohn's disease & 7 & 1.8 & 0.2 \\
\hline & Ulcerative colitis & 4 & 1.0 & 0.1 \\
\hline & $\begin{array}{l}\text { Other (gastric ulcer-diarrhoea-irritable } \\
\text { bowel syndrome) }\end{array}$ & 21 & 5.4 & 0.6 \\
\hline \multirow[t]{3}{*}{ Rheumatologic (19) } & Inflammatory joint disease & 7 & 1.8 & 0.2 \\
\hline & Senescent arthritis & 4 & 1.0 & 0.1 \\
\hline & $\begin{array}{l}\text { Others (Hystiocytosis-Sclerodermia-Bullous } \\
\text { pemphygoid-Deficit IgA.-Lupus) }\end{array}$ & 8 & 2.1 & 0.2 \\
\hline \multirow[t]{4}{*}{ Infectious diseases (18) } & Hepatitis C & 7 & 1.8 & 0.2 \\
\hline & HIV infection & 4 & 1.0 & 0.1 \\
\hline & Hepatitis B & 4 & 1.0 & 0.1 \\
\hline & $\begin{array}{l}\text { Other (infected hip } \\
\text { prostheses-urinary infection) }\end{array}$ & 3 & 0.8 & 0.1 \\
\hline \multirow[t]{5}{*}{ Pediatrics (13) } & Bronchiolitis & 4 & 1.0 & 0.1 \\
\hline & Premature & 4 & 1.0 & 0.1 \\
\hline & Gastro-oesophageal reflux disease & 3 & 0.8 & 0.1 \\
\hline & Febrile seizure & 2 & 0.5 & 0.1 \\
\hline & Cow milk protein allergy & 1 & 0.3 & 0.0 \\
\hline \multirow[t]{4}{*}{ Blood diseases (12) } & Coagulation disorder & 6 & 1.5 & 0.2 \\
\hline & Sickle cell anaemia & 3 & 0.8 & 0.1 \\
\hline & Splenectomy & 2 & 0.5 & 0.1 \\
\hline & Thrombocytopenic purpura & 1 & 0.3 & 0.0 \\
\hline \multirow[t]{3}{*}{ Dermatologic (11) } & Atopic dermatitis & 5 & 1.3 & 0.2 \\
\hline & Eczema & 3 & 0.8 & 0.1 \\
\hline & Acnea & 3 & 0.8 & 0.1 \\
\hline \multirow[t]{2}{*}{ Renal diseases (7) } & Kidney transplant & 3 & 0.8 & 0.1 \\
\hline & $\begin{array}{l}\text { IgA nephropathy, chronic renal } \\
\text { dysfunction, Polycystic kidney disease }\end{array}$ & 4 & 1.0 & 0.1 \\
\hline Ophthalmologic (6) & Glaucoma & 6 & 1.5 & 0.2 \\
\hline Hear, Ear Eye, Nose, Throat (6) & (Vertigo. Neurinoma. Cholesteatoma) & 9 & 2.3 & 0.3 \\
\hline Gynaecologic (4) & Endometriosis & 4 & 1.0 & 0.1 \\
\hline Urologic (4) & $\begin{array}{l}\text { Benign prostatic hyperplasia, } \\
\text { Renal stone disease, Nephrectomy }\end{array}$ & 4 & 1.0 & 0.1 \\
\hline Rare diseases (2) & $\begin{array}{l}\text { Tuberous sclerosis, Tinu syndrome, } \\
\text { Proteus syndrome }\end{array}$ & 3 & 0.5 & 0.1 \\
\hline
\end{tabular}


Table 3 Malaria risk and malaria prophylaxis according to reason for travel of 3442 travellers from Marseille, according to reason for travel in 2009.

\begin{tabular}{lllccc}
\hline & All travellers $N(\%)$ & Tourists $N(\%)$ & Business travellers $N(\%)$ & VFRs ${ }^{\mathrm{a}} N(\%)$ \\
\hline Malaria risk & Type 1 and $2^{\mathrm{b}}$ & $1087(33.8)$ & $734(40.0)$ & $179(34.0)$ & $55(12.5)$ \\
& Type $3^{\mathrm{b}}$ & $2132(66.2)$ & $1100(60.0)$ & $349(66.0)$ & $384(87.5)$ \\
& ND $^{\mathrm{c}}$ & 222 & 139 & 38 & 2 \\
Antimalarial & Doxycycline & $708(37.2)$ & $265(26.7)$ & $114(36.8)$ & $189(53.5)$ \\
& Mefloquine & $127(6.7)$ & $33(3.3)$ & $11(3.5)$ & $70(19.8)$ \\
& Atovaquone-Proguanil & $963(50.6)$ & $665(67.2)$ & $143(46.1)$ & $78(22.1)$ \\
& Chloroquine-Proguanil & $18(0.9)$ & $1(0.1)$ & $3(1)$ & $8(2.3)$ \\
& None & $88(4.6)$ & $27(2.7)$ & $39(12.5)$ & $8(2.3)$ \\
\hline
\end{tabular}

${ }^{\text {a }}$ VFRs $=$ visiting friends and relatives.

b Type 1 = absence of Plasmodium falciparum strains resistant to chloroquine, Type $2=$ presence $P$. falciparum strains resistant to chloroquine, Type $3=$ High prevalence of $P$. falciparum strains resistant to chloroquine and multi-resistant strains. ${ }^{13}$

${ }^{c} \mathrm{ND}=$ non documented. $\%$ were calculated for documented data only.

18-59 years of age and $7.3 \%$ in travellers $<18$ years of age. The most frequent diseases were hypertension, asthma, thyroid diseases, depression and diabetes. The most frequent treatments were cardiovascular and psychotropic medications, which were most commonly used by travellers $\geq 60$ years of age compared to those 18-59 years of age. In total, $29(0.8 \%)$ travellers were immunocompromised (18 travellers because of a chronic disease and 11 travellers because of immunosuppressive drug intake).

\section{Malaria chemoprophylaxis and vaccines}

Overall, $70.7 \%$ of travellers received malaria chemoprophylaxis, mainly atovaquone/proguanil and doxycycline. Two-thirds of travellers travelled to areas where the prevalence of chloroquine resistance was high or where multiresistance was present (group 3 according to the 2009 French classification), ${ }^{13}$ of whom $50.6 \%$ received atovaquone-proguanil, $37.2 \%$ doxycycline and $6.7 \%$ mefloquine (Table 3). Few travellers were prescribed chloroquine/ proguanil, most of them travelling to South India and Madagascar. The choice of antimalarial drug was dependent on the duration of travel (Fig. 2). According to the 2009 French recommendations ${ }^{13}$, a total of 2489 (72.3\%)

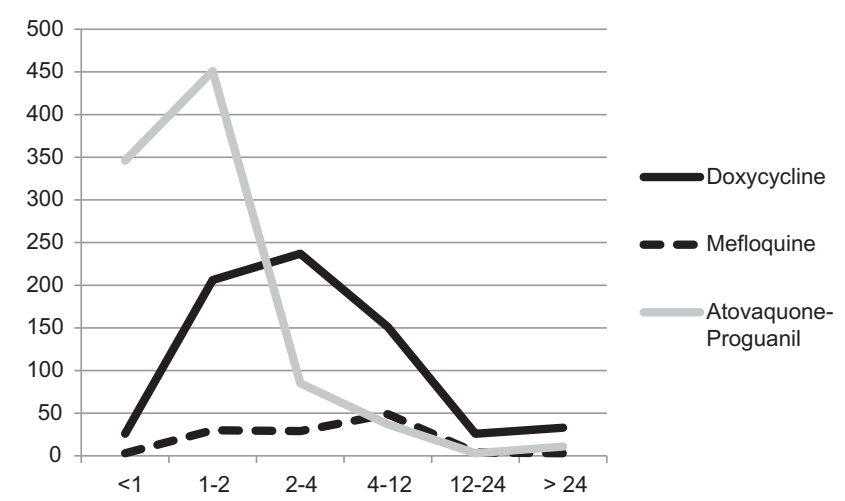

Figure 2 Number of travellers receiving doxycycline, mefloquine or atovaquone-proguanil according to duration of travel, in weeks of 3442 travellers from Marseille, in 2009. travellers had an indication for Yellow fever vaccine. In 23 cases, the vaccination was contraindicated (12 children less than nine months of age, five pregnant women, and seven travellers with immunocompromising conditions). Overall, two-thirds of travellers were immunised previously against tetanus, diphtheria and poliomyelitis (TDP) (Table 4). Tourist travellers were significantly more likely to be immunised against TDP compared to business travellers and VFRs $(p=0.009)$. One-third of travellers were immunised against hepatitis $B$ with no significant differences according to the reason for travel. By contrast, VFRs were significantly less likely to be vaccinated against hepatitis $A$ and typhoid fever before their visit to the clinic and were less likely to receive vaccines against these diseases during the visit compared to other travellers $(p<0.001)$. Age, last minute travel and neurological and psychiatric diseases were the most frequent factors that influenced Yellow fever vaccination and malaria chemoprophylaxis (Table 5).

\section{Discussion}

The mean age (37 years) of the travellers and the predominance of tourists in our survey is similar to the findings of another study that was conducted in Paris ${ }^{7}$ and of international studies that were conducted in travel clinics. ${ }^{14-18}$ In our survey, $>30 \%$ of travellers were business travellers or VFRs, whereas these categories accounted for $11.2 \%-36.1 \%$ in other studies. ${ }^{7,14,15,17}$ The travellers who were seen in Marseille was characterised by the predominance of travel destinations to Sub-Saharan Africa, which may reflect the past colonial history of France and subsequent migration waves, notably in South France. In 2008, $46.4 \%$ of travellers who were consulted at a travel clinic in Paris had a destination to Asia and $39.5 \%$ of travellers to Africa. ${ }^{7}$ South America was the main destination of travellers in a study in Spain, ${ }^{15}$ whereas Thailand was the main destination in a study in Sweden ${ }^{16}$ and India was the main destination in a study in the U.S. ${ }^{14}$ Vaccination coverage against tetanus and diphtheria in the travellers in Marseille was similar to that of other surveys, ${ }^{14}$ whereas the vaccination coverage against hepatitis $B$ was lower. ${ }^{14,17,18}$ This low vaccination rate against hepatitis $B$ reflects the well- 
Table 4 Immunisation status before visit and vaccination provided during visit according to reason for travel of 3442 travellers from Marseille, according to reason for travel in 2009.

\begin{tabular}{|c|c|c|c|c|c|c|c|c|}
\hline \multirow[t]{2}{*}{ Vaccine } & \multicolumn{2}{|l|}{ All travellers } & \multicolumn{2}{|l|}{ Tourists } & \multicolumn{2}{|c|}{ Business travellers } & \multicolumn{2}{|l|}{ VFRs $^{a}$} \\
\hline & $\begin{array}{l}\text { Immunisation }{ }^{\mathrm{b}} \\
N(\%)\end{array}$ & $\begin{array}{l}\text { Vaccination } \\
N(\%)\end{array}$ & $\begin{array}{l}\text { Immunisation } \\
N(\%)\end{array}$ & $\begin{array}{l}\text { Vaccination } \\
N(\%)\end{array}$ & $\begin{array}{l}\text { Immunisation } \\
N(\%)\end{array}$ & $\begin{array}{l}\text { Vaccination } \\
N(\%)\end{array}$ & $\begin{array}{l}\text { Immunisation } \\
N(\%)\end{array}$ & $\begin{array}{l}\text { Vaccination } \\
N(\%)\end{array}$ \\
\hline $\mathrm{TDP}^{\mathrm{C}}$ & $2225(64.6)$ & $681(19.8)$ & $1313(66.5)$ & 393 (19.9) & $344(60.8)$ & $136(24.0)$ & $269(61.0)$ & $85(19.3)$ \\
\hline $\mathrm{HepB}^{\mathrm{d}}$ & $1077(31.3)$ & $142(4.1)$ & 589 (29.9) & $58(2.9)$ & $170(31.1)$ & 41 (7.2) & $137(30.1)$ & $24(5.4)$ \\
\hline $\mathrm{TF}^{\mathrm{e}}$ & 367 (10.6) & 1277 (37.1) & $205(10.4)$ & $600(30.4)$ & 70 (12.4) & $184(32.5)$ & $18(4.1)$ & $60(13.6)$ \\
\hline Hep $A^{f}$ & $591(17.1)$ & 1429 (41.5) & 341 (17.3) & $593(30.1)$ & $116(20.5)$ & $186(32.9)$ & $33(7.5)$ & $60(13.6)$ \\
\hline $\mathrm{JE}^{\mathrm{g}}$ & $2(0.02)$ & $19(0.6)$ & $2(0.1)$ & $7(0.4)$ & $0(0.0)$ & $10(1.8)$ & $0(0.0)$ & $0(0.0)$ \\
\hline Rabies & $24(0.7)$ & $194(5.6)$ & $14(0.7)$ & $104(5.2)$ & $5(0.8)$ & $53(9.3)$ & $1(0.2)$ & $5(1.0)$ \\
\hline
\end{tabular}

a VFR = visiting friends and relatives.

b Travellers were considered immunised based on documented or self-reported previous vaccination and according to French guidelines. ${ }^{13,34}$

c TDP $=$ tetanus, diphtheria, poliomyelitis.

d Hep B $=$ hepatitis $B$.

e $\mathrm{TF}=$ typhoid fever.

${ }^{f}$ Hep $\mathrm{A}=$ hepatitis $\mathrm{A}$.

g JE = Japanese encephalitis.

Table 5 Factors influencing yellow fever vaccination, malaria prophylaxis and traveller's diarrhoea treatment of 3442 travellers from Marseille in 2009.

\begin{tabular}{|c|c|c|c|}
\hline Prescription & Factors & $N$ & $\%$ All travellers \\
\hline \multirow[t]{13}{*}{ Yellow fever vaccination } & Allergy to eggs & ND & \\
\hline & Last minute travel ( $<10$ days before departure) & 427 & 13.2 \\
\hline & $<1$ year of age & 45 & 1.3 \\
\hline & $>60$ years of age & 312 & 9.2 \\
\hline & Intended conception & 18 & 0.6 \\
\hline & Confirmed pregnancy & 8 & 0.2 \\
\hline & Immunocompromised traveller & 14 & 0.4 \\
\hline & Rheumatic disorder immunosupressive medication & 2 & 0.1 \\
\hline & Organ transplant immunosupressive medication & 3 & 0.1 \\
\hline & Immunosuppressive medication for cancer & 1 & 0.0 \\
\hline & $\begin{array}{l}\text { Generalised eczema or psoriasis } \\
\text { immunosupressive medication }\end{array}$ & 1 & 0.0 \\
\hline & HIV infection with $<200$ CD + & 0 & 0.0 \\
\hline & Thymoma-thymectomy & 1 & 0.0 \\
\hline \multirow[t]{14}{*}{ Malaria chemoprophylaxis } & Allergy to doxycycline & ND & \\
\hline & Known intolerance to antimalarials & ND & \\
\hline & Last minute travel ( $<10$ days before departure) & 427 & 13.2 \\
\hline & $<1$ year of age & 45 & 1.3 \\
\hline & $>60$ years of age & 312 & 9.2 \\
\hline & Intended conception & 18 & 0.6 \\
\hline & Confirmed pregnancy & 8 & 0.2 \\
\hline & Neuropsychiatric disorder & 51 & 1.5 \\
\hline & Epilepsy & 14 & 0.4 \\
\hline & Heart rhythm and conduction disorder & 14 & 0.4 \\
\hline & Intake of oral anticoagulants & 12 & 0.4 \\
\hline & Severe renal or hepatic failure & 2 & 0.1 \\
\hline & Splenectomy & 2 & 0.1 \\
\hline & Generalised psoriasis & 1 & 0.0 \\
\hline \multirow[t]{5}{*}{ Traveller's diarrhoea treatment } & $\begin{array}{l}\text { Decreased gastric acid (surgery/proton } \\
\text { pomp inhibitors) }\end{array}$ & 9 & 0.3 \\
\hline & Pregnancy & 8 & 0.2 \\
\hline & HIV infections/AIDS & 4 & 0.1 \\
\hline & Allergy to fluoroquinolone & ND & \\
\hline & Crohn's disease/ulcerative colitis & 2 & 0.1 \\
\hline
\end{tabular}


known reluctance of the French population towards the hepatitis B vaccine. Therefore, the pre-travel visit is an opportunity to provide this routine vaccine.

Our study suggests that the majority of travellers can be given standard pre-travel advice on malaria prophylaxis, Yellow fever vaccination, and travellers' diarrhoea. However, more than one tenth of the travellers reported at least one risk factor for which adjusted advice may be necessary.

In addition, we identified subpopulations of travellers with specific needs, including VFRs, children, seniors, and travellers with chronic medical conditions, accounting for $43 \%$ of the travellers (Fig. 3). Cardiovascular diseases accounted for $50 \%$ of the travel-associated deaths in the American travellers, ${ }^{19}$ whereas these diseases accounted for $27 \%$ of the travel-associated deaths in French travellers. ${ }^{20}$ Cardiovascular diseases are the second most frequent cause of medical evacuations and are responsible for $50 \%$ of the deaths among French travellers during international flights. ${ }^{21}$ In our study, cardiovascular diseases were the most frequent chronic conditions among the travellers. Regarding the possible drug interactions and cardiovascular side effects of antimalarials, travel health specialist should be particularly cautious when advising patients who suffer from heart rhythm and conduction diseases or are taking anticoagulants. We recommend that such patients would benefit from an evaluation by a cardiologist before travelling. Psychiatric disorders were also prominent among travellers, in our experience with depression accounting for most cases, which contraindicates the use of mefloquine. Senior travellers frequently suffer from chronic diseases and take medications; therefore, prescriptions by travel health specialists may lead to drug interactions or side effects in older travellers. The proportion of older travellers will probably increase in the future due to an increase in life expectancy, and a travel medicine specialist will need to have competence in Medicine of the Elderly. Young travellers represented a small proportion of the travellers; however, they pose specific challenges. ${ }^{22,23}$ Notably, there is no clear recommendation in France for malaria chemoprophylaxis in infants who weigh less than $11 \mathrm{~kg}$ who travel to malariaendemic areas where resistance to chloroquine or other antimalarials is highly prevalent. In practice, atovaquone/ proguanil is used in infants who weigh $>5 \mathrm{~kg}$ in Belgium, Canada and the U.S. ${ }^{24}$ French guidelines, mention that atovaquone/proguanil can be used in infant weighing $5-11 \mathrm{~kg},{ }^{13}$ however, it is off-label in France, and practitioners have little protection if adverse events occur. Mefloquine in France is not recommended in infants weighing $<15 \mathrm{~kg}$, although it has proven effective and safe $^{25}$ which therefore do not offer an alternative. An official extension of the indication of both drugs to include use in children $<11 \mathrm{~kg}$ could solve the dilemma. VFRs include both migrants who are returning to their birth country to visit their relatives and second and third generation French-born descendants. ${ }^{26}$ VFRs account for $25-40 \%$ of the travellers to tropical areas. ${ }^{27}$ Because they travel for longer durations often in rural areas and share local food with their family, these travellers are particularly at risk for travel-associated infectious diseases. In $2009,70 \%$ of the malaria cases in the U.S. were observed in VFRs. ${ }^{28}$ A similar pattern has been observed for typhoid fever. ${ }^{29}$ Furthermore, VFRs seek pre-travel advice less frequently than tourists. ${ }^{26}$ The Comorian community is the largest Sub-Saharan migrant community in Marseille, which consists of an estimated 50,000-70,000 individuals. ${ }^{30}$ However, VFRs who travel to Comoros accounted for only $4 \%$ of the travellers who were seen at our pre-travel clinic. This finding is partly because Yellow fever vaccination is not

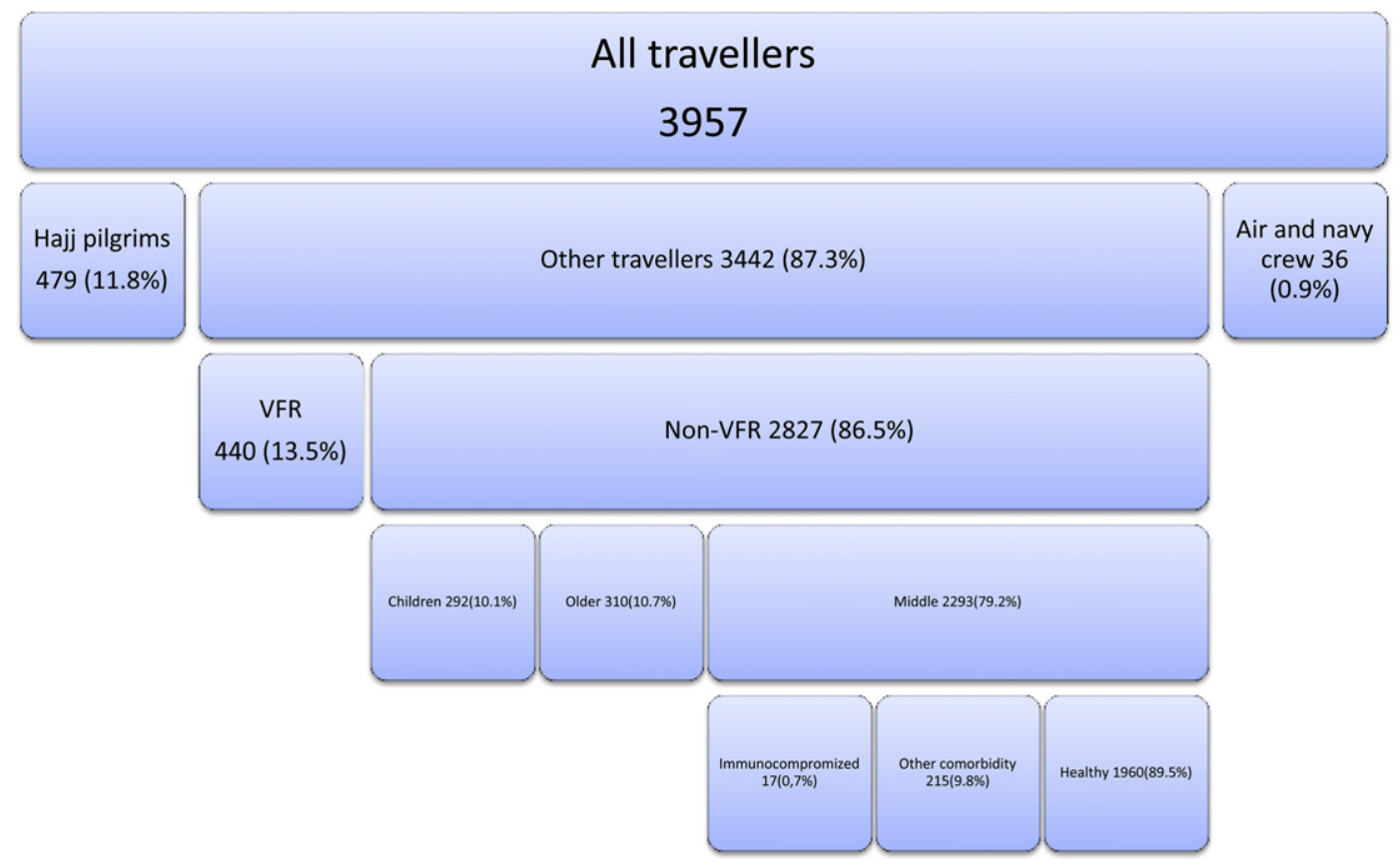

Figure 3 Proportion of at-risk travellers (travellers visiting friends and relative (VFR), children $(<18$ years), older travellers ( $>60$ years)) and travellers with chronic conditions. 
required in Comoros; therefore, a visit to a specialised centre is not mandatory. A visit to a general practitioner may be more acceptable, more accessible, and possibly preferred by this community. However, a study that was conducted in 2003 among Comorians who suffered from malaria upon their return from Comoros demonstrated that most of the travellers did not use chemoprophylaxis because of a lack of information, a belief that being born in Comoros confers protection against malaria and the high cost of antimalarials. ${ }^{31}$ In this context, providing more information regarding the risk of infectious diseases may be one way that allows travellers to prioritise their choice of using chemoprophylaxis according to their financial capacity. Alternatively, reimbursement of malaria prophylaxis by the public French national health insurance system has been proposed ${ }^{32}$ and this may be an option for selected at-risk travellers including those travelling to Comoros.

\section{Conclusions}

Travellers who sought advice at other travel clinics in Marseille or from general practitioners or travellers who did not seek advice at all were not included in our study. Travellers to Europe and North Africa, which are preferred destinations of French travellers, were not captured in our survey. Notably, a study that was conducted in 2008 among European travellers indicated that the majority of travellers with respiratory infections were returning from countries in Europe, and the majority of travellers with acute diarrhoea were returning from North Africa. ${ }^{33}$ Our results demonstrate that travellers who sought advice at our travel clinic are not representative of the entire travelling population but are representative of travellers to tropical areas and particularly to countries at risk for Yellow fever. We believe that the results of our survey can be extrapolated to the French travellers who seek advice at travel clinics in France; however, the proportion of travellers to Africa may be overrepresented in our survey.

Our survey provides insight into the health conditions, travel destinations, travel duration, and pre-travel medical care of an epidemiologically significant population and should facilitate the targeting of risk reduction strategies for this group. Such knowledge could assist in limiting the spread of infections that are related to international travel. We demonstrate that a significant proportion of travellers are at-risk (43\%) because of their travel conditions (VFR), their age, or their health status. This implies that pre-travel advice is quite complex and we recommend that special training should be provided to non-specialists giving pretravel advice. Most complex situations will be better addressed at a specialised travel clinic.

\section{Conflict of interest}

The authors declare that they have no conflicts of interest.

\section{Acknowledgements}

This document (F7A9-62F7-6FE3-18E7-9CC0) was edited by American Journal Experts (support@journalexperts.com).

\section{References}

1. Chen LH, Wilson ME. The role of the traveler in emerging infections and magnitude of travel. Med Clin North Am 2008; 92:1409-32. xi.

2. Gautret $P$, Schlagenhauf $P$, Gaudart J, Castelli F, Brouqui $P$, von Sonnenburg F, et al. Multicenter EuroTravNet/GeoSentinel Study of travel-related infectious diseases in Europe. Emerg Infect Dis 2009;15:1783-90.

3. Armand L. French tourists abroad in 2006: results from the survey "Follow up of tourists preferences". Bull Epid Hebdo 2007;25-26:218-21.

4. Van Herck K, Van Damme P, Castelli F, Zuckerman J, Nothdurft $\mathrm{H}$, Dahlgren $\mathrm{AL}$, et al. Knowledge, attitudes and practices in travel-related infectious diseases: the European Airport Survey. J Travel Med 2004;11:3-8.

5. Jeannel D, Lassel L, Dorléans F, Gautier A, Jauffret-Roustide $M$. Infectious risks perception when traveling abroad, attitudes and practices of the French population, 2006. Bull Epid Hebdo 2007;25-26:221-4.

6. Leroy JP, de Gentile L, Legros F. Enquête sur les centres de vaccinations internationales en France métropolitaine: état des lieux et propositions. Bull Epid Hebdo 2006;23-24:164-5.

7. Goesch JN, Simons de Fanti A, Béchet S, Consigny PH. Comparison of knowledge on travel related health risks and their prevention among humanitarian aid workers and other travellers consulting at the Institut Pasteur travel clinic in Paris, France. Travel Med Infect Dis 2010;8:364-72.

8. Dia A, Gautret P, Adheossi E, Bienaimé A, Gaillard C, Simon F, et al. Illness in French travelers to Senegal: prospective cohort follow-up and sentinel surveillance data. J Travel Med 2010; 17:296-302.

9. Gautret P, Yong W, Soula G, Parola P, Brouqui P, DelVecchio Good MJ. Determinants of tetanus, diphtheria and poliomyelitis vaccinations among Hajj pilgrims, Marseille, France. Eur J Public Health 2010;20:438-42.

10. Gautret P, Vu Hai V, Sani S, Doutchi M, Parola P, Brouqui P. Protective measures against acute respiratory symptoms in French pilgrims participating in the Hajj of 2009. J Travel Med 2011;18:53-5.

11. http://www.insee. $\mathrm{fr} / \mathrm{fr} /$ methodes/default.asp?page $=$ nomenclatures/pcs2003/liste_n1.htm [accessed 11.06.12].

12. Van De Winkel K, Van den Daele A, Van Gompel A, Van den Ende J. Factors influencing standard pretravel health advice-a study in Belgium. J Travel Med 2005;12:327-31.

13. Haut conseil de la santé publique, Direction générale de la santé. Health recommendations for travellers 2009 (for health professionals). Bull Epid Hebdo 2009;23-24:237-56.

14. Larocque RC, Rao SR, Lee J, Ansdell V, Yates JA, Schwartz BS, et al. Global TravEpiNet: a national consortium of clinics providing care to international travelers-analysis of demographic characteristics, travel destinations, and pretravel healthcare of high-risk US international travelers, 2009-2011. Clin Infect Dis 2012;54:455-62.

15. Valerio L, Martinez $O$, Sabria M, Esteve M, Urbiztondo L, Roca C. High-risk travel abroad overtook low-risk travel from 1999 to 2004: characterization and trends in 2,622 Spanish travellers. J Travel Med 2005;12:327-31.

16. Angelin $M$, Evengard $B$, Palmgren $H$. Travel and vaccination patterns: a report from a travel medicine clinic in northern Sweden. Scand J Infect Dis 2011;43:714-20.

17. Lee VJ, Wilder-Smith A. Travel characteristics and health practices among travellers at the travellers' health and vaccination clinic in Singapore. Ann Acad Med Singap 2006;35: 667-73.

18. Chinwa Lo S, Mascheretti M, Chaves Tdo S, Lopes MH. Travelers' vaccinations: experience from the Travelers' Clinic of 
Hospital das Clínicas, University of São Paulo School of Medicine. Rev Soc Bras Med Trop 2008;41:474-8.

19. Haargarten SW, Baker TD, Guptill K. Overseas fatalities of United States citizen travelers: an analysis of deaths related to international travel. Ann Emerg Med 1991;20:622-6.

20. Jeannel D, Allain-loos S, Bonmarin I, Capek I, CaserioSchönemann $C$, Che $D$, et al. Les décès de français lors d'un séjour à l'étranger et leurs causes. Bull Epid Hebdo 2006; 23-24:166-8.

21. Touze JE, Fourcade L, Heno P, Van de Walle JP, Mafart B, N'Guyen $\mathrm{H}$. Le risque cardio-vasculaire pour le voyageur. Med Trop (Mars) 1997;57:461-4.

22. Hagmann S, Neugebauer R, Schwartz E, Perret C, Castelli F, Barnett ED, et al. Illness in children after international travel: analysis from the GeoSentinel Surveillance Network. Pediatrics 2010; May; 125:e1072-80.

23. Hunziker T, Berger C, Staubli G, Tschopp A, Weber R, Nadal D, et al. Profile of travel-associated illness in children, Zürich, Switzerland. J Travel Med 2012;19:158-62.

24. World Health Organization. International travel and health. Geneva, Switzerland: WHO; 2012.

25. Schlagenhauf $P$, Adamcova M, Regep L, Schaerer MT, Bansod S, Rhein HG. Use of mefloquine in children - a review of dosage, pharmacokinetics and tolerability data. Malar J 2011;10:292.

26. Leder K, Tong S, Weld L, Kain KC, Wilder-Smith A, von Sonnenburg $F$, et al. Illness in travelers visiting friends and relatives: a review of the GeoSentinel Surveillance Network. Clin Infect Dis 2006;439:1185-93.

27. Castelli F. Human mobility and disease: a global challenge. J Travel Med 2004;11:1-2.
28. Mali S, Tan KR, Arguin PMDivision of Parasitic Diseases and Malaria, Center for Global Health; Centers for Disease Control and Prevention. Malaria surveillance-United States, 2009. MMWR 2011;60:1-15.

29. Ackers ML, Puhr ND, Tauxe RV, Mintz ED. Laboratory-based surveillance of Salmonella serotype Typhi infections in the United States: antimicrobial resistance on the rise. JAMA 2000; 283:2668-73.

30. Parola P, Gazin P, Pradines B, Parzy D, Delmont J, Brouqui P. Marseille: a surveillance site for malaria from the Comoros islands. J Travel Med 2004;11:184-6.

31. Parola P, Soula G, Gazin P, Foucault C, Delmont J, Brouqui $P$. Fever in travelers returning from tropical areas: prospective observational study of 613 cases hospitalised in Marseilles, France 1999-2003. Travel Med Infect Dis 2006; 4:61-70.

32. Pistone $T$, Schwarzinger $M$, Chauvin $P$, Ezzedine $K$, Receveur MC, Djossou F, et al. Reimbursement of malaria chemoprophylaxis for travellers from Europe to Sub-Saharan Africa: cost-effectiveness analysis from the perspective of the French national health insurance system. Health Policy 2008;88:186-99.

33. Field V, Gautret $P$, Schlagenhauf $P$, Burchard GD, Caumes E, Jensenius $M$, et al. Travel and migration associated infectious diseases morbidity in Europe, 2008. BMC Infect Dis 2010;10:330.

34. Haut conseil de la santé publique, Direction générale de la santé. Vaccination schedule and recommendations from the "Haut conseil de la santé publique" in France. Bull Epid Hebdo 2009;16-17:145-76. 